\title{
UNITED STATES COURT OF APPEALS FOR THE NINTH CIRCUIT
}

KELSEY CASCADIA ROSE JULIANA;

XiUHTEZCATL TONATIUH M., through his Guardian Tamara RoskeMartinez; ALEXANDER LOZNAK; JACOB LEBEL; ZEALAND B., through his Guardian Kimberly Pash-Bell; AVERY M., through her Guardian Holly McRae; SAHARA V., through her Guardian Toa Aguilar; KIRAN ISAAC OOMMEN; TIA MARIE HATTON; ISAAC V., through his Guardian Pamela Vergun; MıKO V., through her Guardian Pamel Vergun; HAZEL V., through her Guardian Margo Van Ummerson; SoPHIE K., through her Guardian Dr. James Hansen; JAIME B., through her Guardian Jamescita Peshlakai; JOURNEY Z., through his Guardian Erika Schneider; VICTORIAB., through her Guardian Daisy Calderon; NATHANIEL B., through his Guardian Sharon Baring; AJI P., through his Guardian Helaina Piper; LEVI D., through his Guardian Leigh-Ann Draheim; JAYDEN F., through her Guardian Cherri Foytlin; NICHOLAS V., through his Guardian Marie Venner; EARTH GUARDIANS, a

No. $18-36082$

D.C. No.

6:15-cv-01517AA

OPINION 
nonprofit organization; FUTURE GENERATIONS, through their Guardian Dr. James Hansen, Plaintiffs-Appellees, V.

UNITEDSTATES OF AMERICA; MARY B. NEUMAYR, in her capacity as Chairman of Council on Environmental Quality; MICK MulvaneY, in his official capacity as Director of the Office of Management and the Budget; KELVINK.DROEGEMEIR, in his official capacity as Director of the Office of Science and Technology Policy; Dan Brouillette, in his official capacity as Secretary of Energy; U.S.DEPARTMENT OF THE INTERIOR; DAVIDL.BERNHARDT, in his official capacity as Secretary of Interior; U.S. DEPARTMENT OF TRANSPORTATION; ELAINE L. CHAO, in her official capacity as Secretary of Transportation; UNITEDSTATES DEPARTMENT OF AGRICULTURE; SONNY PERDUE, in his official capacity as Secretary of Agriculture; UNITEDSTATES DEPARTMENT OF COMMERCE; WILBUR ROSS, in his official capacity as Secretary of Commerce; UnITEDSTATES DEPARTMENT OF DEFENSE; MARK T. 
ESPER, in his official capacity as Secretary of Defense; UNITED STATES DEPARTMENT OF STATE; MiCHAEL R. POMPEO, in his official capacity as Secretary of State; ANDREW WHEELER, in his official capacity as Administrator of the EPA; OFFICE OF THE PRESIDENT OF THE UNITEDSTATES;U.S. ENVIRONMENTAL PROTECTION AGENCY; U.S. DEPARTMENT OF ENERGY; DONALD J. TRUMP, in his official capacity as President of the United States,

Defendants-Appellants.

Appeal from the United States District Court for the District of Oregon Ann L. Aiken, District Judge, Presiding

Argued and Submitted June 4, 2019 Portland, Oregon

Filed January 17, 2020

Before: Mary H. Murguia and Andrew D. Hurwitz, Circuit Judges, and Josephine L. Staton, ${ }^{*}$ District Judge.

Opinion by Judge Hurwitz; Dissent by Judge Staton

* The Honorable Josephine L. Staton, United States District Judge for the CentralDistrict of California, sitting by designation. 


\section{SUMMARY ${ }^{* *}$}

\section{Climate Change / Standing}

The panel reversed the district court's interlocutory orders in an action brought by an environmental organization and individual plaintiffs against the federal government, alleging climate-change related injuries to the plaintiffs caused by the federal government continuing to "permit, authorize, and subsidize" fossil fuel; and remanded to the district court with instructions to dismiss for lack of Article III standing.

Some plaintiffs claimed psychological harms, others impairment to recreational interests, others exacerbated medical conditions, and others damage to property. Plaintiffs alleged violations of their constitutional rights, and sought declaratory relief and an injunction ordering the government to implement a plan to "phase out fossil fuel emissions and draw down excess atmospheric [carbon dioxide].”

The panel held that: the record left little basis for denying that climate change was occurring at an increasingly rapid pace; copious expert evidence established that the unprecedented rise in atmospheric carbon dioxide levels stemmed from fossil fuel combustion and will wreak havoc on the Earth's climate if unchecked; the record conclusively established that the federal government has long understood the risks of fossil fuel use and increasing carbon dioxide emissions; and the record established that the government's

** This summary constitutes no part of the opinion of the court. It has been prepared by court staff for the convenience of the reader. 
contribution to climate change was not simply a result of inaction.

The panel rejected the government's argument that plaintiffs' claims must proceed, if at all, under the Administrative Procedure Act ("APA”). The panel held that because the APA only allows challenges to discrete agency decisions, the plaintiffs could not effectively pursue their constitutional claims - whatever their merits - under that statute.

The panel considered the three requirements for whether plaintiffs had Article III standing to pursue their constitutional claims. First, the panel held that the district court correctly found that plaintiffs claimed concrete and particularized injuries. Second, the panel held that the district court properly found the Article III causation requirement satisfied for purposes of summary judgment because there was at least a genuine factual dispute as to whether a host of federal policies were a "substantial factor" in causing the plaintiffs' injuries. Third, the panel held that plaintiffs' claimed injuries were not redressable by an Article III court. Specifically, the panel held that it was beyond the power of an Article III court to order, design, supervise, or implement the plaintiffs' requested remedial plan where any effective plan would necessarily require a host of complex policy decisions entrusted to the wisdom and discretion of the executive and legislative branches.

The panel reluctantly concluded that the plaintiffs' case must be made to the political branches or to the electorate at large.

District Judge Staton dissented, and would affirm the district court. Judge Staton wrote that plaintiffs brought suit to enforce the most basic structural principal embedded in 
our system of liberty: that the Constitution does not condone the Nation's willful destruction. She would hold that plaintiffs have standing to challenge the government's conduct, have articulated claims under the Constitution, and have presented sufficient evidence to press those claims at trial. 


\section{COUNSEL}

Jeffrey Bossert Clark (argued), Assistant Attorney General; Andrew C. Mergen, Sommer H. Engels, and Robert J. Lundman, Attorneys; Eric Grant, Deputy Assistant Attorney General; Environment and Natural Resources Division, United States Department of Justice, Washington, D.C.; for Defendants-Appellants.

Julia A. Olson (argued), Wild Earth Advocates, Eugene, Oregon; Philip L. Gregory, Gregory Law Group, Redwood City, California; Andrew K. Rodgers, Law Offices of Andrea K. Rodgers, Seattle, Washington; for PlaintiffsAppellees.

Theodore Hadzi-Antich and Ryan D. Walters, Texas Public Policy Foundation, Austin, Texas, for Amici Curiae Nuckels Oil Co., Inc. DBA Merit Oil Company; Libety Packing Company, LLC; Western States Trucking Association; and National Federation of Independent Business Small Business Legal Center.

Richard K. Eichstaedt, University Legal Assistance, Spokane, Washington, for Amici Curiae Eco-Justice Ministries; Interfaith Moral Action on Climate; General Synod of the United Church of Christ; Temple Beth Israel of Eugene, Oregon; National Advocacy Center of the Sisters of the Good Shepherd; Leadership Counsel of the Sisters Servants of the Immaculate Heart of Mary of Monroe, Michigan; Sisters of Mercy of the Americas' Institute Leadership Team; GreenFaith; Leadership Team of the Sisters of Providence of Saint-Mary-of-the-Woods Indiana; Leadership Conference of Women Religious; Climate Change Task Force of the Sisters of Providence of SaintMary-of-the-Woods; Quaker Earthcare Witness; Colorado 
Interfaith Power and Light; and the Congregation of Our Lady of Charity of the Good Shepherd, U.S. Provinces.

Dr. Curtis FJ Doebbler, Law Office of Dr. Curtis FJ Doebbler, San Antonio, Texas; D. InderComar, Comar LLP, San Francisco, California; for Amici Curiae International Lawyers for International Law.

Wendy B. Jacobs, Director; Shaun A. Goho, Deputy Director; Emmett Environmental Law \& Policy Clinic, Harvard Law School, Cambridge, Massachusetts; for Amici Curiae Public Health Experts, Public Health Organizations, and Doctors.

David Bookbinder, Niskanen Center, Washington, D.C., for Amicus Curiae Niskanen Center.

Courtney B. Johnson, Crag Law Center, Portland, Oregon, for Amici Curiae League of Women Voters of the United States and League of Women Voters of Oregon.

Oday Salim, Environmental Law \& Sustainability Clinic; Julian D. Mortensen and David M. Uhlmann, Professors; Alexander Chafetz, law student; University of Michigan Law School, Ann Arbor, Michigan; for Amicus Curiae Sunrise Movement Education Fund.

Zachary B. Corrigan, Food \& Water Watch, Inc., Washington, D.C., for Amici Curiae Food \& Water Watch, Inc.; Friends of the Earth - US; and Greenpeace, Inc.

Patti Goldman, Earthjustice, Seattle, Washington; Sarah H. Burt, Earthjustice, San Francisco, California; for Amici Curiae EarthRights International, Center for Biological 
Diversity, Defenders of Wildlife, and Union of Concerned Scientists.

David Hunter and William John Snape III, American University, Washington College of Law, Washington, D.C., for Amici Curiae International Environmental Law and Environmental Law Alliance Worldwide-US.

Timothy M. Bechtold, Bechtold Law Firm PLLC, Missoula, Montana, for Amici Curiae Members of the United States Congress.

Rachael Paschal Osborn, Vashon, Washington, for Amici Curiae Environmental History Professors.

Thomas J. Beers, Beers Law Offices, Seeley Lake, Montana; Irma S. Russell, Professor, and Edward A. Smith, Missouri Chair in Law, the Constitution, and Society, University of Missouri-Kansas City School of Law, Kansas City, Missouri; W. Warren H. Binford Professor or Law \& Director, Clinical Law Program, Willamette University, Salem, Oregon; for Amicus Curiae Zero Hour on Behalf of Approximately 32,340 Children and Young People.

Helen H. Kang, Environmental Law and Justice Clinic, Golden Gate University School of Law, San Francisco, California; James R. May and Erin Daly, Dignity Rights Project, Delaware Law School, Wilmington, Delaware; for Amici Curiae Law Professors.

Toby J. Marshall, Terrell Marshall Law Group PLLC, Seattle, Washington, for Amici Curiae Guayaki Sustainable Rainforest Products, Inc.; Royal Blue Organics; Organically Grown Company; Bliss Unlimited, LLC, dba Coconut Bliss; Hummingbird Wholesale; Aspen Skiing Company, LLC; 
Protect Our Winters; National Ski Areas Association; Snowsports Industries America; and American Sustainable Business Council.

Alejandra Núñez and Andres Restrepo, Sierra Club, Washington, D.C.; Joanne Spalding, Sierra Club, Oakland, California; for Amicus Curiae Sierra Club. 


\section{OPINION}

HURWITZ, Circuit Judge:

In the mid-1960s, a popular song warned that we were "on the eve of destruction."1 The plaintiffs in this case have presented compelling evidence that climate change has brought that eve nearer. A substantial evidentiary record documents that the federal government has long promoted fossil fuel use despite knowing that it can cause catastrophic climate change, and that failure to change existing policy may hasten an environmental apocalypse.

The plaintiffs claim that the government has violated their constitutional rights, including a claimed right under the Due Process Clause of the Fifth Amendment to a "climate system capable of sustaining human life." The central issue before us is whether, even assuming such a broad constitutional right exists, an Article III court can provide the plaintiffs the redress they seek-an order requiring the government to develop a plan to "phase out fossil fuel emissions and draw down excess atmospheric CO2." Reluctantly, we conclude that such relief is beyond our constitutional power. Rather, the plaintiffs' impressive case for redress must be presented to the political branches of government.

I.

The plaintiffs are twenty-one young citizens, an environmental organization, and a "representative of future generations." Their original complaint named as defendants

1 Barry McGuire, Eve of Destruction, on Eve of Destruction (Dunhill Records, 1965). 
the President, the United States, and federal agencies (collectively, "the government"). The operative complaint accuses the government of continuing to "permit, authorize, and subsidize" fossil fuel use despite long being aware of its risks, thereby causing various climate-change related injuries to the plaintiffs. Some plaintiffs claim psychological harm, others impairment to recreational interests, others exacerbated medical conditions, and others damage to property. The complaint asserts violations of: (1) the plaintiffs' substantive rights under the Due Process Clause of the Fifth Amendment; (2) the plaintiffs' rights under the Fifth Amendment to equal protection of the law; (3) the plaintiffs' rights under the Ninth Amendment; and (4) the public trust doctrine. The plaintiffs seek declaratory relief and an injunction ordering the government to implement a plan to "phase out fossil fuel emissions and draw down excess atmospheric [carbon dioxide]."

The district court denied the government's motion to dismiss, concluding that the plaintiffs had standing to sue, raised justiciable questions, and stated a claim for infringement of a Fifth Amendment due process right to a "climate system capable of sustaining human life." The court defined that right as one to be free from catastrophic climate change that "will cause human deaths, shorten human lifespans, result in widespread damage to property, threaten human food sources, and dramatically alter the planet's ecosystem." The court also concluded that the

2 The plaintiffs also assert that section 201 of the Energy Policy Act of 1992, Pub. L. No. 102-486, § 201, 106 Stat. 2776, 2866 (codified at 15 U.S.C. $\S 717 b(c)$ ), which requires expedited authorization for certain natural gas imports and exports "without modification or delay," is unconstitutionalon its face and as applied. The plaintiffs a lso challenge DOE/FE Order No. 3041, which authorizes exports of liquefied natural gas from the proposed Jordan Cove terminal in Coos Bay, Oregon. 
plaintiffs had stated a viable "danger-creation due process claim" arising from the government's failure to regulate third-party emissions. Finally, the court held that the plaintiffs had stated a public trust claim grounded in the Fifth and the Ninth Amendments.

The government unsuccessfully sought a writ of mandamus. In re United States, 884 F.3d 830, 837-38 (9th Cir. 2018). Shortly thereafter, the Supreme Court denied the government's motion for a stay of proceedings. United States v. U.S. Dist. Court for Dist. of Or., 139 S. Ct. 1 (2018). Although finding the stay request "premature," the Court noted that the "breadth of respondents' claims is striking ... and the justiciability of those claims presents substantial grounds for difference of opinion.” Id.

The government then moved for summary judgment and judgment on the pleadings. The district court granted summary judgment on the Ninth Amendment claim, dismissed the President as a defendant, and dismissed the equal protection claim in part. ${ }^{3}$ But the court otherwise denied the government's motions, again holding that the plaintiffs had standing to sue and finding that they had presented sufficient evidence to survive summary judgment. The court also rejected the government's argument that the plaintiffs' exclusive remedy was under the Administrative Procedure Act (“APA”), 5 U.S.C. § 702 et seq.

The district court initially declined the government's request to certify those orders for interlocutory appeal. But, while considering a second mandamus petition from the government, we invited the district court to revisit

3 The court found that age is not a suspect class, but allowed the equalprotection claim to proceed on a fundamental rights theory. 
certification, noting the Supreme Court's justiciability concerns. United States v. U.S. Dist. Court for the Dist. of Or., No. 18-73014, Dkt. 3; see In re United States, 139 S. Ct. 452, 453 (2018) (reiterating justiciability concerns in denying a subsequent stay application from the government). The district court then reluctantly certified the orders denying the motions for interlocutory appeal under 28 U.S.C. § 1292(b) and stayed the proceedings, while "stand[ing] by its prior rulings ... as well as its belief that this case would be better served by further factual development at trial.” Juliana v. United States, No. 6:15-cv01517-AA, 2018 WL 6303774, at *3 (D. Or. Nov. 21, 2018). We granted the government's petition for permission to appeal.

\section{II.}

The plaintiffs have compiled an extensive record, which at this stage in the litigation we take in the light most favorable to their claims. See Plumhoff v. Rickard, 572 U.S. 765, 768 (2014). The record leaves little basis for denying that climate change is occurring at an increasingly rapid pace. It documents that since the dawn of the Industrial Age, atmospheric carbon dioxide has skyrocketed to levels not seen for almost three million years. For hundreds of thousands of years, average carbon concentration fluctuated between 180 and 280 parts per million. Today, it is over 410 parts per million and climbing. Although carbon levels rose gradually after the last Ice Age, the most recent surge has occurred more than 100 times faster; half of that increase has come in the last forty years.

Copious expert evidence establishes that this unprecedented rise stems from fossil fuel combustion and will wreak havoc on the Earth's climate if unchecked. Temperatures have already risen 0.9 degrees Celsius above 
pre-industrial levels and may rise more than 6 degrees Celsius by the end of the century. The hottest years on record all fall within this decade, and each year since 1997 has been hotter than the previous average. This extreme heat is melting polar ice caps and may cause sea levels to rise 15 to 30 feet by 2100 . The problem is approaching "the point of no return." Absent some action, the destabilizing climate will bury cities, spawn life-threatening natural disasters, and jeopardize critical food and water supplies.

The record also conclusively establishes that the federal government has long understood the risks of fossil fuel use and increasing carbon dioxide emissions. As early as 1965, the Johnson Administration cautioned that fossil fuel emissions threatened significant changes to climate, global temperatures, sea levels, and other stratospheric properties. In 1983, an Environmental Protection Agency ("EPA”) report projected an increase of 2 degrees Celsius by 2040, warning that a "wait and see" carbon emissions policy was extremely risky. And, in the 1990s, the EPA implored the government to act before it was too late. Nonetheless, by 2014, U.S. fossil fuel emissions had climbed to 5.4 billion metric tons, up substantially from 1965 . This growth shows no signs of abating. From 2008 to 2017, domestic petroleum and natural gas production increased by nearly $60 \%$, and the country is now expanding oil and gas extraction four times faster than any other nation.

The record also establishes that the government's contribution to climate change is not simply a result of inaction. The government affirmatively promotes fossil fuel use in a host of ways, including beneficial tax provisions, permits for imports and exports, subsidies for domestic and 
overseas projects, and leases for fuel extraction on federal land. ${ }^{4}$

\section{A.}

The government by and large has not disputed the factual premises of the plaintiffs' claims. But it first argues that those claims must proceed, if at all, under the APA. We reject that argument. The plaintiffs do not claim that any individual agency action exceeds statutory authorization or, taken alone, is arbitrary and capricious. See 5 U.S.C. $\S 706(2)(A),(C)$. Rather, they contend that the totality of various government actions contributes to the deprivation of constitutionally protected rights. Because the APA only allows challenges to discrete agency decisions, see Lujan $v$. Nat'l Wildlife Fed'n, 497 U.S. 871, 890-91 (1990), the plaintiffs cannot effectively pursue their constitutional claims - whatever their merits—under that statute.

The defendants argue that the APA's "comprehensive remedial scheme" for challenging the constitutionality of agency actions implicitly bars the plaintiffs' freestanding constitutional claims. But, even if some constitutional challenges to agency action must proceed through the APA, forcing all constitutional claims to follow its strictures would

4 The programs and policies identified by the plaintiffs include: (1) the Bureau of Land Management's authorization of leases for 107 coal tracts and 95,000 oil and gas wells; (2) the Export-Import Bank's provision of $\$ 14.8$ billion for overseas petroleum projects; (3) the Department of Energy's approval of over 2 million barrels of crude oil imports; (4) the Department of Agriculture's approval of timber cutting on federal land; (5) the undervaluing of royalty rates for federal lea sing; (6) tax subsidies for purchasing fuel-inefficient sport-utility vehicles; (7) the "intangible drilling costs" and "percentage depletion allowance" tax code provisions, 26 U.S.C. §§ 263(c), 613; and (8) the government's use of fossil fuels to power its own buildings and vehicles. 
bar plaintiffs from challenging violations of constitutional rights in the absence of a discrete agency action that caused the violation. See Sierra Club v. Trump, 929 F.3d 670, 694, 696 (9th Cir. 2019) (stating that plaintiffs could "bring their challenge through an equitable action to enjoin unconstitutional official conduct, or under the judicial review provisions of the [APA]"); Navajo Nation v. Dep't of the Interior, 876 F.3d 1144, 1172 (9th Cir. 2017) (holding "that the second sentence of $\S 702$ waives sovereign immunity broadly for all causes of action that meet its terms, while § 704's 'final agency action' limitation applies only to APA claims"). Because denying "any judicial forum for a colorable constitutional claim" presents a "serious constitutional question," Congress's intent through a statute to do so must be clear. See Webster v. Doe, 486 U.S. 592, 603 (1988) (quoting Bowen v. Mich. Acad. of Family Physicians, 476 U.S. 667, 681 n.12 (1986)); see also Allen v. Milas, 896 F.3d 1094, 1108 (9th Cir. 2018) (“After Webster, we have assumed that the courts will be open to review of constitutional claims, even if they are closed to other claims."). Nothing in the APA evinces such an intent. ${ }^{5}$ Whatever the merits of the plaintiffs' claims, they may proceed independently of the review procedures mandated by the APA. See Sierra Club, 929 F.3d at 698-99 ("Any constitutional challenge that Plaintiffs may advance under the APA would exist regardless of whether they could also assert an APA claim .... [C]laims challenging agency

5 The government relies upon Armstrong v. Exceptional Child Center, Inc., 575 U.S. 320, 328-29 (2015), and Seminole Tribe of Florida v. Florida, 517 U.S. 44, 74-76 (1996), both of which held that statutory remedial schemes implicitly barred freestanding equitable claims. Neither case, however, involved claims by the pla intiffs that the federal government was violating their constitutional rights. See Armstrong, 575 U.S. at 323-24 (claiming that state officials had violated a federal statute); Seminole Tribe, 517 U.S. at 51-52 (same). 
actions - particularly constitutional claims-may exist wholly apart from the APA.”); Navajo Nation, 876 F.3d at 1170 (explaining that certain constitutional challenges to agency action are "not grounded in the APA").

B.

The government also argues that the plaintiffs lack Article III standing to pursue their constitutional claims. To have standing under Article III, a plaintiff must have (1) a concrete and particularized injury that (2) is caused by the challenged conduct and (3) is likely redressable by a favorable judicial decision. See Friends of the Earth, Inc. $v$. Laidlaw Envtl. Servs. (TOC), Inc., 528 U.S. 167, 180-81 (2000); Jewel v. NSA, 673 F.3d 902, 908 (9th Cir. 2011). A plaintiff need only establish a genuine dispute as to these requirements to survive summary jud gment. See Cent. Delta Water Agency v. United States, 306 F.3d 938, 947 (9th Cir. 2002).

\section{1.}

The district court correctly found the injury requirement met. At least some plaintiffs claim concrete and particularized injuries. Jaime B., for example, claims that she was forced to leave her home because of water scarcity, separating her from relatives on the Navajo Reservation. See Trump v. Hawaii, 138 S. Ct. 2392, 2416 (2018) (finding separation from relatives to be a concrete injury). Levi D. had to evacuate his coastal home multiple times because of flooding. See Maya v. Centex Corp., 658 F.3d 1060, 107071 (9th Cir. 2011) (finding diminution in home property value to be a concrete injury). These injuries are not simply “"conjectural' or 'hypothetical;"' at least some of the plaintiffs have presented evidence that climate change is affecting them now in concrete ways and will continue to do 
so unless checked. Lujan v. Defs. of Wildlife, 504 U.S. 555, 560 (1992) (quoting Whitmore v. Arkansas, 495 U.S. 149, 155 (1990)); cf. Ctr. for Biological Diversity v. U.S. Dep't of Interior, 563 F.3d 466, 478 (D.C. Cir. 2009) (finding no standing because plaintiffs could "only aver that any significant adverse effects of climate change 'may' occur at some point in the future").

The government argues that the plaintiffs' alleged injuries are not particularized because climate change affects everyone. But, "it does not matter how many persons have been injured" if the plaintiffs' injuries are "concrete and personal.” Massachusetts v. EPA, 549 U.S. 497, 517 (2007) (quoting Lujan, 504 U.S. at 581 (Kennedy, J., concurring)); see also Novak v. United States, 795 F.3d 1012, 1018 (9th Cir. 2015) (" $[T]$ he fact that a harm is widely shared does not necessarily render it a generalized grievance.”) (alteration in original) (quoting Jewel, 673 F.3d at 909). And, the Article III injury requirement is met if only one plaintiff has suffered concrete harm. See Hawaii, 138 S. Ct. at 2416; Town of Chester, N.Y. v. Laroe Estates, Inc., 137 S. Ct. 1645, 1651 (2017) ("At least one plaintiff must have standing to seek each form of relief requested in the complaint.... For all relief sought, there must be a litigant with standing.”).

The district court also correctly found the Article III causation requirement satisfied for purposes of summary judgment. Causation can be established "even if there are multiple links in the chain," Mendia v. Garcia, 768 F.3d 1009, 1012 (9th Cir. 2014), as long as the chain is not "hypothetical or tenuous," Maya, 658 F.3d at 1070 (quoting Nat'l Audubon Soc'y, Inc. v. Davis, 307 F.3d 835, 849 (9th Cir. 2002), amended on denial of reh'g, 312 F.3d 416 (9th Cir. 2002)). The causal chain here is sufficiently established. 
The plaintiffs' alleged injuries are caused by carbon emissions from fossil fuel production, extraction, and transportation. A significant portion of those emissions occur in this country; the United States accounted for over 25\% of worldwide emissions from 1850 to 2012, and currently accounts for about 15\%. See Massachusetts, 549 U.S. at 524-25 (finding that emissions amounting to about $6 \%$ of the worldwide total showed cause of alleged injury "by any standard"). And, the plaintiffs' evidence shows that federal subsidies and leases have increased those emissions. About 25\% of fossil fuels extracted in the United States come from federal waters and lands, an activity that requires authorization from the federal government. See 30 U.S.C. §§ 181-196 (establishing legal framework governing the disposition of fossil fuels on federal land), $\S 201$ (authorizing the Secretary of the Interior to lease land for coal mining).

Relying on Washington Environmental Council v. Bellon, 732 F.3d 1131, 1141-46 (9th Cir. 2013), the government argues that the causal chain is too attenuated because it depend sin part on theindependent actions of third parties. Bellon held that the causal chain between local agencies' failure to regulate five oil refineries and the plaintiffs' climate-change related injuries was "too tenuous to support standing" because the refineries had a "scientifically indiscernible" impact on climate change. Id. at 1143-44. But the plaintiffs here do not contend that their injuries were caused by a few isolated agency decisions. Rather, they blame a host of federal policies, from subsidies to drilling permits, spanning "over 50 years," and direct actions by the government. There is at least a genuine factual dispute as to whether those policies were a "substantial factor" in causing the plaintiffs' injuries. Mendia, 768 F.3d at 1013 (quoting Tozzi v. U.S. Dep't of 
Health \& Human Servs., 271 F.3d 301, 308 (D.C. Cir. 2001)).

The more difficult question is whether the plaintiffs' claimed injuries are redressable by an Article III court. In analyzing that question, we start by stressing what the plaintiffs do and do not assert. They do not claim that the government has violated a statute or a regulation. They do not assert the denial of a procedural right. Nor do they seek damages under the Federal Tort Claims Act, 28 U.S.C. $\S 2671$ et seq. Rather, their sole claim is that the government has deprived them of a substantive constitutional right to a "climate system capable of sustaining human life," and they seek remedial declaratory and injunctive relief.

Reasonable jurists can disagree about whether the asserted constitutional right exists. Compare Clean Air Council v. United States, 362 F. Supp. 3d 237, 250-53 (E.D. Pa. 2019) (finding no constitutional right), with Juliana, 217 F. Supp. 3d at 1248-50; see also In re United States, 139 S. Ct. at 453 (reiterating "that the 'striking' breadth of plaintiffs' below claims 'presents substantial grounds for difference of opinion'”). In analyzing redressability, however, we assume its existence. See M.S. v. Brown, 902 F.3d 1076, 1083 (9th Cir. 2018). But that merely begins our analysis, because "not all meritorious legal claims are redressable in federal court." Id. To establish Article III redressability, the plaintiffs must show that the relief they seek is both (1) substantially likely to redress their injuries; and (2) within the district court's power to award. Id. Redress need not be guaranteed, but it must be more than “merely speculative.” Id. (quoting Lujan, 504 U.S. at 561). 
The plaintiffs first seek a declaration that the government is violating the Constitution. But that relief alone is not substantially likely to mitigate the plaintiffs' asserted concrete injuries. A declaration, although undoubtedly likely to benefit the plaintiffs psychologically, is unlikely by itself to remediate their alleged injuries absent further court action. See Clean Air Council, 362 F. Supp. 3d at 246, 249; Steel Co. v. Citizens for a Better Env't, 523 U.S. 83, 107 (1998) ("By the mere bringing of his suit, every plaintiff demonstrates his belief that a favorable judgment will make him happier. But although a suitor may derive great comfort and joy from the fact that the United States Treasury is not cheated, that a wrongdoer gets his just deserts, or that the Nation's laws are faithfully enforced, that psychic satisfaction is not an acceptable Article III remedy because it does not redress a cognizable Article III injury.”); see also Friends of the Earth, 528 U.S. at 185 ("[A] plaintiff must demonstrate standing separately for each form of relief sought.”).

The crux of the plaintiffs' requested remedy is an injunction requiring the government not only to cease permitting, authorizing, and subsidizing fossil fuel use, but also to prepare a plan subject to judicial approval to draw down harmful emissions. The plaintiffs thus seek not only to enjoin the Executive from exercising discretionary authority expressly granted by Congress, see, e.g., 30 U.S.C. $\S 201$ (authorizing the Secretary of the Interior to lease land for coal mining), but also to enjoin Congress from exercising power expressly granted by the Constitution over public lands, see U.S. Const. art. IV, § 3, cl. 2 ("The Congress shall have Power to dispose of and make all needful Rules and Regulations respecting the Territory or other Property belonging to the United States.”). 
As an initial matter, we note that although the plaintiffs contended at oral argument that they challenge only affirmative activities by the government, an order simply enjoining those activities will not, according to their own experts' opinions, suffice to stop catastrophic climate change or even ameliorate their injuries. ${ }^{6}$ The plaintiffs' experts opine that the federal government's leases and subsidies have contributed to global carbon emissions. But they do not show that even the total elimination of the challenged programs would halt the growth of carbon dioxide levels in the atmosphere, let alone decrease that growth. Nor does any expert contend that elimination of the challenged pro-carbon fuels programs would by itself prevent further injury to the plaintiffs. Rather, the record shows that many of the emissions causing climate change happened decades ago or come from foreign and non-governmental sources.

Indeed, the plaintiffs' experts make plain that reducing the global consequences of climate change demands much more than cessation of the government's promotion of fossil fuels. Rather, these experts opine that such a result calls for no less than a fundamental transformation of this country's energy system, if not that of the industrialized world. One expert opines that atmospheric carbon reductions must come "largely via reforestation," and include rapid and immediate decreases in emissions from many sources. "[L]eisurely reductions of one of two percent per year," he explains, "will not suffice." Another expert has opined that although the required emissions reductions are "technically feasible," they can be achieved only through a comprehensive plan for "nearly complete decarbonization" that includes both an "unprecedently rapid build out" of renewable energy and a

6 The operative complaint, however, also seems to challenge the government's inaction. 
"sustained commitment to infrastructure transformation over decades." And, that commitment, another expert emphasizes, must include everything from energy efficient lighting to improved public transportation to hydrogenpowered aircraft.

The plaintiffs concede that their requested relief will not alone solve global climate change, but they assert that their "injuries would be to some extent ameliorated." Relying on Massachusetts v. EPA, the district court apparently found the redressability requirement satisfied because the requested relief would likely slow or reduce emissions. See 549 U.S. at 525-26. That case, however, involved a procedural right that the State of Massachusetts was allowed to assert "without meeting all the normal standards for redressability;" in that context, the Court found redressability because "there [was] some possibility that the requested relief [would] prompt the injury-causing party to reconsider the decision that allegedly harmed the litigant." Id. at 517-18, 525-26 (quoting Lujan, 504 U.S. at 572 n.7). The plaintiffs here do not assert a procedural right, but rather a substantive due process claim. ${ }^{7}$

7 The dissent reads Massachusetts to hold that "a perceptible reduction in the advance of climate change is sufficient to redress a plaintiff's climate change-induced harms." Diss. at 47. But Massachusetts "permitted a State to challenge EPA's refusal to regulate greenhouse gas emissions," Am. Elec. Power Co., Inc. v. Connecticut, 564 U.S. 410, 420 (2011), finding that as a sovereign it was "entitled to special solicitude in [the] standing analysis," Ariz. State Legislature $v$. Ariz. Indep. Redistricting Comm'n, 135 S. Ct. 2652, 2664 n.10 (2015) (quoting Massachusetts, 549 U.S. at 520). Here, in contrast, the plaintiffs are not sovereigns, and a substantive right, not a procedural one, is at issue. See Massachusetts, 549 U.S. at 517-21, 525-26; see also Lujan, 504 U.S. at $572 \mathrm{n} .7$ ("There is this much truth to the assertion that 'procedural rights' are special: The person who has been accorded a 
We are therefore skeptical that the first redressability prong is satisfied. But even assuming that it is, the plaintiffs do not surmount the remaining hurdle - establishing that the specific relief they seek is within the power of an Article III court. There is much to recommend the adoption of a comprehensive scheme to decrease fossil fuel emissions and combat climate change, both as a policy matter in general and a matter of national survival in particular. But it is beyond the power of an Article III court to order, design, supervise, or implement the plaintiffs' requested remedial plan. As the opinions of their experts make plain, any effective plan would necessarily require a host of complex policy decisions entrusted, for better or worse, to the wisd om and discretion of the executive and legislative branches. See Brown, 902 F.3d at 1086 (finding the plaintiff's requested declaration requiring the government to issue driver cards "incompatible with democratic principles embedded in the structure of the Constitution"). These decisions range, for example, from determining how much to invest in public transit to how quickly to transition to renewable energy, and plainly require consideration of "competing social, political, and economic forces," which must be made by the People's "elected representatives, rather than by federal judges interpreting the basic charter of Government for the entire country." Collins v. City of Harker Heights, 503 U.S. 115, 128-29 (1992); see Lujan, 504 U.S. at 559-60 ("[S]eparation of powers depends largely upon common understanding of what activities are appropriate to legislatures, to executives, and to courts.”).

procedural right to protect his concrete interests can assert that right without meeting all the normal standards for redressability and immediacy.”). 
The plaintiffs argue that the district court need not itself make policy decisions, because if their general request for a remedial plan is granted, the political branches can decide what policies will best "phase out fossil fuel emissions and draw down excess atmospheric CO2." To be sure, in some circumstances, courts may order broad injunctive relief while leaving the "details of implementation" to the government's discretion. Brown v. Plata, 563 U.S. 493, 537-38 (2011). But, even under such a scenario, the plaintiffs' request for a remedial plan would subsequently require the judiciary to pass judgment on the sufficiency of the government's response to the order, which necessarily would entail a broad range of policymaking. And inevitably, this kind of plan will demand action not only by the Executive, but also by Congress. Absent court intervention, the political branches might conclude-however inappropriately in the plaintiffs' view - that economic or defense considerations called for continuation of the very programs challenged in this suit, or a less robust approach to addressing climate change than the plaintiffs believe is necessary. "But we cannot substitute our own assessment for the Executive's [or Legislature's] predictive judgments on such matters, all of which 'are delicate, complex, and involve large elements of prophecy." Hawaii, 138 S. Ct. at 2421 (quoting Chi. \& S. Air Lines, Inc. v. Waterman S.S. Corp., 333 U.S. 103, 111 (1948)). And, given the complexity and long-lasting nature of global climate change, the court would be required to supervise the government's compliance with any suggested plan for many decades. See Nat. Res. Def. Council, Inc. v. EPA, 966 F.2d 1292, 1300 (9th Cir. 1992) ("Injunctive relief could involve 
extraordinary supervision by this court.... [and] may be inappropriate where it requires constant supervision.”). ${ }^{8}$

As the Supreme Court recently explained, "a constitutional directive or legal standards" must guide the courts' exercise of equitable power. Rucho $v$. Common Cause, 139 S. Ct. 2484, 2508 (2019). Rucho found partisan gerrymandering claims presented political questions beyond the reach of Article III courts. Id. at 2506-07. The Court did not deny extreme partisan gerrymandering can violate the Constitution. See id. at 2506; id. at 2514-15 (Kagan, J., dissenting). But, it concluded that there was no "limited and precise" standard discernible in the Constitution for redressing the asserted violation. Id. at 2500. The Court

${ }^{8}$ However belatedly, the political branches are currently debating such action. Many resolutions and plans have been introduced in Congress, ranging from discrete measures to encourage clean energy innovation to the "Green New Deal" and comprehensive proposals for taxing carbon and transitioning all sectors of the economy away from fossil fuels. See, e.g., H.R. Res. 109, 116th Cong. (2019); S.J. Res. 8, 116th Cong. (2019); Enhancing Fossil Fuel Energy Carbon Technology Act, S. 1201, 116th Cong. (2019); Climate Action Now Act, H.R. 9, 116th Cong. (2019); Methane Waste Prevention Act, H.R. 2711, 116th Cong. (2019); Clean Energy Standard Act, S. 1359, 116th Cong. (2019); National Climate Bank Act, S. 2057, 116th Cong. (2019); Carbon Pollution Transparency Act, S. 1745, 116th Cong. (2019); Leading Infrastructure for Tomorrow's America Act, H.R. 2741, 116th Cong. (2019); Buy Clean Transparency Act, S. 1864, 116th Cong. (2019); Carbon Capture Modernization Act, H.R. 1796, 116th Cong. (2019); Challenges \& Prizes for Climate Act, H.R. 3100, 116th Cong. (2019); Energy Innovation and Carbon Dividend Act, H.R. 763, 116th Cong. (2019); Climate Risk Disclosure Act, S. 2075, 116th Cong. (2019); Clean Energy for America Act, S. 1288, 116th Cong. (2019). The proposed legislation, consistent with the opinions of the plaintiffs' experts, envisions that tackling this global problem involves the exercise of discretion, trade-offs, international cooperation, private-sector partnerships, and other value judgments ill-suited for an Article III court. 
rejected the plaintiffs' proposed standard because unlike the one-person, one-vote rule in vote dilution cases, it was not "relatively easy to administer as a matter of math." Id. at 2501.

Rucho reaffirmed that redressability questions implicate the separation of powers, noting that federal courts "have no commission to allocate political power and influence" without standards to guide in the exercise of such authority. See id. at 2506-07, 2508. Absent those standards, federal judicial power could be "unlimited in scope and duration," and would inject "the unelected and politically unaccountable branch of the Federal Government [into] assuming such an extraordinary and unprecedented role.” Id. at 2507; see also Lexmark Int'l, Inc. v. Static Control Components, Inc., 572 U.S. 118, 125 (2014) (noting the "separation-of-powers principles underlying” standing doctrine); Brown, 902 F.3d at 1087 (stating that "in the context of Article III standing, ... federal courts must respect their 'proper-and properly limited-role ... in a democratic society”" (quoting Gill v. Whitford, 138 S. Ct. 1916, 1929 (2018)). Because "it is axiomatic that 'the Constitution contemplates that democracy is the appropriate process for change,’” Brown, 902 F.3d at 1087 (quoting Obergefell v. Hodges, 135 S. Ct. 2584, 2605 (2015)), some questions-even those existential in nature-are the province of the political branches. The Court found in Rucho that a proposed standard involving a mathematical comparison to a baseline election map is too difficult for the judiciary to manage. See 139 S. Ct. at 2500-02. It is impossible to reach a different conclusion here.

The plaintiffs' experts opine that atmospheric carbon levels of 350 parts per million are necessary to stabilize the global climate. But, even accepting those opinions as valid, 
they do not suggest how an order from this Court can achieve that level, other than by ordering the government to develop a plan. Although the plaintiffs' invitation to get the ball rolling by simply ordering the promulgation of a plan is beguiling, it ignores that an Article III court will thereafter be required to determine whether the plan is sufficient to remediate the claimed constitutional violation of the plaintiffs' right to a "climate system capable of sustaining human life." We doubt that any such plan can be supervised or enforced by an Article III court. And, in the end, any plan is only as good as the court's power to enforce it.

C.

Our dissenting colleague quite correctly notes the gravity of the plaintiffs' evidence; we differ only as to whether an Article III court can provide their requested redress. In suggesting that we can, the dissent reframes the plaintiffs' claimed constitutional right variously as an entitlement to "the country's perpetuity," Diss. at 35-37, 39, or as one to freed om from "the amount of fossil-fuel emissions that will irreparably devastate our Nation," id. at 57. But if such broad constitutional rights exist, we doubt that the plaintiffs would have Article III standing to enforce them. Their alleged individual injuries do not flow from a violation of these claimed rights. Indeed, any injury from the dissolution of the Republic would be felt by all citizens equally, and thus would not constitute the kind of discrete and particularized injury necessary for Article III standing. See Friends of the Earth, 528 U.S. at 180-81. A suit for a violation of these reframed rights, like one for a violation of the Guarantee Clause, would also plainly be nonjusticiable. See, e.g., Rucho, 139 S. Ct. at 2506 ("This Court has several times concluded, however, that the Guarantee Clause does not provide the basis for a justiciable claim.”) (citing Pac. States 
Tel. \& Tel. Co. v. Oregon, 223 U.S. 118, 149 (1912)); Luther v. Borden, 48 U.S. 1, 36-37, 39 (1849).

More importantly, the dissent offers no metrics for judicial determination of the level of climate change that would cause "the willful dissolution of the Republic," Diss. at 40, nor for measuring a constitutionally acceptable "perceptible reduction in the advance of climate change," $i d$. at 47. Contrary to the dissent, we cannot find Article III redressability requirements satisfied simply because a court order might "postpone[] the day when remedial measures become insufficiently effective." Id. at 46; see Brown, 902 F.3d at 1083 ("If, however, a favorable judicial decision would not require the defendant to redress the plaintiff's claimed injury, the plaintiff cannot demonstrate redressability[.]"). Indeed, as the dissent recognizes, a guarantee against government conduct that might threaten the Union-whether from political gerrymandering, nuclear proliferation, Executive misconduct, or climate change-has traditionally been viewed by Article III courts as "not separately enforceable." Id. at 39. Nor has the Supreme Court recognized "the perpetuity principle" as a basis for interjecting the judicial branch into the policy-making purview of the political branches. See id. at 42.

Contrary to the dissent, we do not "throw up [our] hands" by concluding that the plaintiffs' claims are nonjusticiable. Id. at 33. Rather, we recognize that "Article III protects liberty not only through its role in implementing the separation of powers, but also by specifying the defining characteristics of Article III judges." Stern v. Marshall, 564 U.S. 462, 483 (2011). Not every problem posing a threat - even a clear and present danger - to the American Experiment can be solved by federal judges. As Judge Cardozo once aptly warned, a judicial commission does not 
confer the power of "a knight-errant, roaming at will in pursuit of his own ideal of beauty or of goodness;" rather, we are bound "to exercise a discretion informed by tradition, methodized by analogy, disciplined by system."” Benjamin N. Cardozo, The Nature of the Judicial Process 141 (1921). ${ }^{9}$

The dissent correctly notes that the political branches of government have to date been largely deaf to the pleas of the plaintiffs and other similarly situated individuals. But, although inaction by the Executive and Congress may affect the form of judicial relief ordered when there is Article III standing, it cannot bring otherwise nonjusticiable claims within the province of federal courts. See Rucho, 139 S. Ct. at 2507-08; Gill, 138 S. Ct. at 1929 ("'Failure of political will does not justify unconstitutional remedies.' ... Our power as judges ... rests not on the default of politically accountable officers, but is instead grounded in and limited by the necessity of resolving, according to legal principles, a plaintiff's particular claim of legal right.” (quoting Clinton v. City of New York, 524 U.S. 417, 449 (1998) (Kennedy, J., concurring))); Brown, 902 F.3d at 1087 ("The absence of a law, however, has never been held to constitute a 'substantive result' subject to judicial review[.]”).

The plaintiffs have made a compelling case that action is needed; it will be increasingly difficult in light of that record

9 Contrary to the dissent, we do not find this to be a political question, although that doctrine's factors often overlap with redressability concerns. Diss. at 51-61; Republic of Marshall Islands $v$. United States, 865 F.3d 1187, 1192 (9th Cir. 2017)("Whether examined under the ... the redressability prong of standing, or the political question doctrine, the analysis stems from the same separation-ofpowers principle-enforcement of this treaty provision is not committed to the judicial branch. Although these a re distinct doctrines . . . there is significant overlap.”). 
for the political branches to deny that climate change is occurring, that the government has had a role in causing it, and that our elected officials have a moral responsibility to seek solutions. We do not dispute that the broad judicial relief the plaintiffs seek could well goad the political branches into action. Diss. at 45-46, 49-50, 57-61. We reluctantly conclude, however, that the plaintiffs' case must be made to the political branches or to the electorate at large, the latter of which can change the composition of the political branches through the ballot box. That the other branches may have abdicated their responsibility to remediate the problem does not confer on Article III courts, no matter how well-intentioned, the ability to step into their shoes.

\section{III.}

For the reasons above, we reverse the certified orders of the district court and remand this case to the district court with instructions to dismiss for lack of Article III standing. ${ }^{10}$

\section{REVERSED.}

STATON, District Judge, dissenting:

In these proceedings, the government accepts as fact that the United States has reached a tipping point crying out for a concerted response-yet presses ahead toward calamity. It is as if an asteroid were barreling toward Earth and the government decided to shut down our only defenses.

10 The plaintiffs' motion for an injunction pending appeal, Dkt. 21, is DENIED. Their motions for judicial notice, Dkts. 134, 149, are GRANTED. 
Seeking to quash this suit, the government bluntly insists that it has the absolute and unreviewable power to destroy the Nation.

My colleagues throw up their hands, concluding that this case presents nothing fit for the Judiciary. On a fundamental point, we agree: No case can singlehandedly prevent the catastrophic effects of climate change predicted by the government and scientists. But a federal court need not manage all of the delicate foreign relations and regulatory minutiae implicated by climate change to offer real relief, and the mere fact that this suit cannot alone halt climate change does not mean that it presents no claim suitable for judicial resolution.

Plaintiffs bring suit to enforce the most basic structural principle embedded in our system of ordered liberty: that the Constitution does not condone the Nation's willful destruction. So viewed, plaintiffs' claims adhere to a judicially administrable standard. And considering plaintiffs seek no less than to forestall the Nation's demise, even a partial and temporary reprieve would constitute meaningful redress. Such relief, much like the desegregation orders and statewide prison injunctions the Supreme Court has sanctioned, would vindicate plaintiffs' constitutional rights without exceeding the Judiciary's province. For these reasons, I respectfully dissent. ${ }^{1}$

${ }^{1}$ I a gree with the majority that plaintiffs need not bring their claims under the APA. See Franklin v. Massachusetts, 505 U.S. 788, 801 (1992); Webster v. Doe, 486 U.S. 592, 603-04 (1988). 
As the majority recognizes, and the government does not contest, carbon dioxide ("CO${ }_{2}$ ”) and other greenhouse gas ("GHG") emissions created by burning fossil fuels are devastating the planet. Maj. Op. at 14-15. According to one of plaintiffs' experts, the inevitable result, absent immediate action, is "an inhospitable future ... marked by rising seas, coastal city functionality loss, mass migrations, resource wars, food shortages, heat waves, mega-storms, soil depletion and desiccation, freshwater shortage, public health system collapse, and the extinction of increasing numbers of species." Even government scientists ${ }^{2}$ project that, given current warming trends, sea levels will rise two feet by 2050, nearly four feet by 2070, over eight feet by 2100, 18 feet by 2150 , and over 31 feet by 2200 . To put that in perspective, a three-foot sea level rise will make two million American homes uninhabitable; a rise of approximately 20 feet will result in the total loss of Miami, New Orleans, and other coastal cities. So, as described by plaintiffs' experts, the injuries experienced by plaintiffs are the first small wave in an oncoming tsunami-now visible on the horizon of the not-so-distant future- that will destroy the United States as we currently know it.

What sets this harm apart from all others is not just its magnitude, but its irreversibility. The devastation might look and feel somewhat different if future generations could simply pick up the pieces and restore the Nation. But plaintiffs' experts speak of a certain level of global warming as "locking in" this catastrophic damage. Put more starkly by plaintiffs’ expert, Dr. Harold R. Wanless, “[a]tmospheric

2 NOAA, Technical Rep. NOS CO-OPS 083, Global and Regional Sea Level Rise Scenarios for the United States 23 (Jan. 2017). 
warming will continue for some 30 years after we stop putting more greenhouse gasses into the atmosphere. But that warmed atmosphere will continue warming the ocean for centuries, and the accumulating heat in the oceans will persist for millennia" (emphasis added). Indeed, another of plaintiffs' experts echoes, "[t]he fact that GHGs dissipate very slowly from the atmosphere ... and that the costs of taking $\mathrm{CO}_{2}$ out of the atmosphere through non-biological carbon capture and storage are very high means that the consequences of GHG emissions should be viewed as effectively irreversible" (emphasis added). In other words, "[g]iven the self-reinforcing nature of climate change," the tipping point may well have arrived, and we may be rapidly approaching the point of no return.

Despite countless studies over the last half century warning of the catastrophic consequences of anthropogenic greenhouse gas emissions, many of which the government conducted, the government not only failed to act but also "affirmatively promote[d] fossil fuel use in a host of ways." Maj. Op. at 15. According to plaintiffs' evidence, our nation is crumbling - at our government's own hand-into a wasteland. In short, the government has directly facilitated an existential crisis to the country's perpetuity. ${ }^{3}$

\section{II.}

In tossing this suit for want of standing, the majority concedes that the children and young adults who brought suit have presented enough to proceed to trial on the first two aspects of the inquiry (injury in fact and traceability). But

${ }^{3}$ My a steroid analogy would therefore be more accurate if I posited a scenario in which the government itself accelerated the asteroid towards the earth before shutting down our defenses. 
the majority provides two-and-a-half reasons for concluding that plaintiffs' injuries are not redressable. After detailing its "skeptic[ism]" that the relief sought could "suffice to stop catastrophic climate change or even ameliorate [plaintiffs'] injuries[,]" Maj. Op. at 23-25, the majority concludes that, at any rate, a court would lack any power to award it. In the majority's view, the relief sought is too great and unsusceptible to a judicially administrable standard.

To explain why I disagree, I first step back to define the interest at issue. While standing operates as a threshold issue distinct from the merits of the claim, "it often turns on the nature and source of the claim asserted." Warth v. Seldin, 422 U.S. 490, 500 (1975). And, unlike the majority, I believe the government has more than just a nebulous "moral responsibility" to preserve the Nation. Maj. Op. at 31-32.

A.

The Constitution protects the right to "life, liberty, and property, to free speech, a free press, [and] freedom of worship and assembly." W. Virginia State Bd. of Educ. v. Barnette, 319 U.S. 624, 638 (1943). Through "reasoned judgment," the Supreme Court has recognized that the Due Process Clause, enshrined in the Fifth and Fourteenth Amendments, also safeguards certain "interests of the person so fundamental that the [government] must accord them its respect." Obergefell v. Hodges, 135 S. Ct. 2584, 2598 (2015). These include the right to marry, Loving $v$. Virginia, 388 U.S. 1, 12 (1967), to maintain a family and rear children, M.L.B. v. S.L.J., 519 U.S. 102, 116 (1996), and to pursue an occupation of one's choosing, Schware v. Bd. of Bar Exam., 353 U.S. 232, 238-39 (1957). As fund amental rights, these "may not be submitted to vote; they depend on the outcome of no elections." Lucas v. Forty-Fourth Gen. Assembly, 
377 U.S. 713, 736 (1964) (quoting Barnette, 319 U.S. at 638).

Some rights serve as the necessary predicate for others; their fundamentality therefore derives, at least in part, from the necessity to preserve other fundamental constitutional protections. Cf., e.g., Timbs v. Indiana, 139 S. Ct. 682, 689 (2019) (deeming a right fundamental because its deprivation would "undermine other constitutional liberties"). For example, the right to vote "is of the essence of a democratic society, and any restrictions on that right strike at the heart of representative government." Reynolds v. Sims, 377 U.S. 533, 555 (1964). Because it is "preservative of all rights," the Supreme Court has long regarded suffrage "as a fundamental political right." Yick Wo v. Hopkins, 118 U.S. 356, 370 (1886). This holds true even though the right to vote receives imperfect express protection in the Constitution itself: While several amendments proscribe the denial or abridgement of suffrage based on certain characteristics, the Constitution does not guarantee the right to vote $a b$ initio. See U.S. Const. amends. XV, XIX, XXIV, XXVI; cf. U.S. Const. art. I, § 4, cl. 1.

Much like the right to vote, the perpetuity of the Republic occupies a central role in our constitutional structure as a "guardian of all other rights," Plyler v. Doe, 457 U.S. 202, 217 n.15 (1982). "Civil liberties, as guaranteed by the Constitution, imply the existence of an organized society ...." Cox v. New Hampshire, 312 U.S. 569, 574 (1941); see also The Ku Klux Cases, 110 U.S. 651, 657-68 (1884). And, of course, in our system, that organized society consists of the Union. Without it, all the liberties protected by the Constitution to live the good life are meaningless. 
This observation is hardly novel. After securing independence, George Washington recognized that "the destiny of unborn millions" rested on the fate of the new Nation, cautioning that "whatever measures have a tendency to dissolve the Union, or contribute to violate or lessen the Sovereign Authority, ought to be considered as hostile to the Liberty and Independency of America[.]" President George Washington, Circular Letter of Farewell to the Army (June 8, 1783). Without the Republic's preservation, Washington warned, "there is a natural and necessary progression, from the extreme of anarchy to the extreme of Tyranny; and that arbitrary power is most easily established on the ruins of Liberty abused to licentiousness.” Id.

When the Articles of the Confederation proved ill-fitting to the task of safeguarding the Union, the framers formed the Constitutional Convention with "the great object" of "preserv[ing] and perpetuat[ing]" the Union, for they believed that "the prosperity of America depended on its Union.” The Federalist No. 2, at 19 (John Jay) (E. H. Scott ed., 1898); see also Letter from James Madison to Thomas Jefferson (Oct. 24, 1787) ${ }^{4}$ ("It appeared to be the sincere and unanimous wish of the Convention to cherish and preserve the Union of the States.”). In pressing New York to ratify the Constitution, Alexander Hamilton spoke of the gravity of the occasion: "The subject speaks its own importance; comprehending in its consequences nothing less than the existence of the Union, the safety and welfare of the parts of which it is composed-the fate of an empire, in many respects the most interesting in the world." The Federalist No. 1, at 11 (Alexander Hamilton) (E. H. Scott ed., 1898). In light of this animating principle, it is fitting that the

${ }^{4}$ Available at https://founders.archives.gov/documents/Jefferson/0 1-12-02-0274. 
Preamble declares that the Constitution is intended to secure "the Blessings of Liberty" not just for one generation, but for all future generations_our "Posterity."

The Constitution's structure reflects this perpetuity principle. See Alden v. Maine, 527 U.S. 706, 713 (1999) (examining how "[v]arious textual provisions of the Constitution assume" a structural principle). In taking the Presidential Oath, the Executive must vow to "preserve, protect and defend the Constitution of the United States," U.S. Const. art. II, § 1, cl. 8, and the Take Care Clause obliges the President to "take Care that the Laws be faithfully executed,” U.S. Const. art. II, § 3 . Likewise, though generally not separately enforceable, Article IV, Section 4 provides that the "United States shall guarantee to every State in this Union a Republican Form of Government, and shall protect each of them against Invasion; and ... against domestic Violence.” U.S. Const. art. IV, § 4; see also New York v. United States, 505 U.S. 144, 184-85 (1992).

Less than a century after the country's founding, the perpetuity principle undergirding the Constitution met its greatest challenge. Faced with the South's secession, President Lincoln reaffirmed that the Constitution did not countenance its own destruction. "[T]he Union of these States is perpetual[,]" he reasoned in his First Inaugural Address, because "[p]erpetuity is implied, if not expressed, in the fundamental law of all national governments. It is safe to assert that no government proper ever had a provision in its organic law for its own termination.” President Abraham Lincoln, First Inaugural Address (Mar. 4, 1861). In justifying this constitutional principle, Lincoln drew from history, observing that "[t]he Union is much older than the Constitution." Id. He reminded his fellow citizens, "one of 
the declared objects for ordaining and establishing the Constitution was 'to form a more perfect Union."” Id. (emphasis added) (quoting U.S. Const. pmbl.). While secession manifested the existential threat most apparently contemplated by the Founders-political dissolution of the Union - the underlying principle applies equally to its physical destruction.

This perpetuity principle does not amount to "a right to live in a contaminant-free, healthy environment." Guertin $v$. Michigan, 912 F.3d 907, 922 (6th Cir. 2019). To be sure, the stakes can be quite high in environmental disputes, as pollution causes tens of thousands of premature deaths each year, not to mention disability and diminished quality of life. ${ }^{5}$ Many abhor living in a polluted environment, and some pay with their lives. But mine-run environmental concerns "involve a host of policy choices that must be made by ... elected representatives, rather than by federal judges interpreting the basic charter of government[.]" Collins v. City of Harker Heights, 503 U.S. 115, 129 (1992). The perpetuity principle is not an environmental right at all, and it does not task the courts with determining the optimal level of environmental regulation; rather, it prohibits only the willful dissolution of the Republic. ${ }^{6}$

5 See, e.g., Andrew L. Goodkind et al., Fine-Scale Damage Estimates of Particulate Matter Air Pollution Reveal Opportunities for Location-Specific Mitigation of Emissions, in 116 Proceedings of the National Academy of Sciences 8775, 8779 (2019) (estimating that fine particulate matter caused 107,000 premature deaths in 2011).

${ }^{6}$ Unwilling to a cknowledge that the very nature of the climate crisis places this case in a category of one, the government argues that "the Constitution does not provide judicial remedies for every social and economic ill." For support, the government cites Lindsey v. Normet, 
That the principle is structural and implicit in our constitutional system does not render it any less enforceable. To the contrary, our Supreme Court has recognized that "[t]here are many [] constitutional doctrines that are not spelled out in the Constitution" but are nonetheless enforceable as "historically rooted principle[s] embedded in the text and structure of the Constitution." Franchise Tax Bd. of California v. Hyatt, 139 S. Ct. 1485, 1498-99 (2019). For instance, the Constitution does not in express terms provide for judicial review, Marbury v. Madison, 5 U.S. 137, 176-77 (1803); sovereign immunity (outside of the Eleventh Amendment's explicit restriction), Alden, 527 U.S. at 73536; the anticommandeering doctrine, Murphy v. NCAA, 138 S. Ct. 1461, 1477 (2018); or the regimented tiers of scrutiny applicable to many constitutional rights, see, e.g., Turner Broad. Sys., Inc. v. FCC, 512 U.S. 622, 641-42 (1994). Yet these doctrines, as well as many other implicit principles, have become firmly entrenched in our constitutional landscape. And, in an otherwise justiciable case, a private litigant may seek to vindicate such structural principles, for they "protect the individual as well" as the Nation. See Bond v. United States, 564 U.S. 211, 222, 225-26 (2011); INS. v. Chadha, 462 U.S. 919, 935-36 (1983).

In Hyatt, for instance, the Supreme Court held that a state could not be sued in another state's courts without its consent. Although nothing in the text of the Constitution expressly forbids such suits, the Court concluded that they

405 U.S. 56, 74 (1972), which held Oregon's wrongful detainer statute governing landlord/tenant disputes constitutional. The perpetuity principle, however, cabins the right and a voids a ny slippery slope. While the principle's goal is to preserve the most funda mental individual rights to life, liberty, and property, it is not triggered absent an existential threat to the country arising from a "point of no return" that is, at least in part, of the government's own making. 
contravened "the 'implicit ordering of relationships within the federal system necessary to make the Constitution a workable governing charter and to give each provision within that document the full effect intended by the Framers."' Hyatt, 139 S. Ct. at 1492 (quoting Nevada $v$. Hall, 440 U.S. 410, 433 (1979) (Rehnquist, J., dissenting)). So too here.

Nor can the perpetuity principle be rejected simply because the Court has not yet had occasion to enforce it as a limitation on government conduct. Only over time, as the Nation confronts new challenges, are constitutional principles tested. For instance, courts did not recognize the anticommandeering doctrine until the 1970s because "[f]ederal commandeering of state governments [was] such a novel phenomenon.” Printz v. United States, 521 U.S. 898, 925 (1997). And the Court did not recognize that cell-site data fell within the Fourth Amendment until 2018. In so holding, the Court rejected “a 'mechanical interpretation' of the Fourth Amendment” because "technology has enhanced the Government's capacity to encroach upon areas normally guarded from inquisitive eyes[.]" Carpenter v. United States, 138 S. Ct. 2206, 2214 (2018). Thus, it should come as no surprise that the Constitution's commitment to perpetuity only now faces judicial scrutiny, for never before has the United States confronted an existential threat that has not only gone unremedied but is actively backed by the government.

The mere fact that we have alternative means to enforce a principle, such as voting, does not diminish its constitutional stature. Americans can vindicate federalism, separation of powers, equal protection, and voting rights through the ballot box as well, but that does not mean these constitutional guarantees are not independently enforceable. 
By its very nature, the Constitution "withdraw[s] certain subjects from the vicissitudes of political controversy, to place them beyond the reach of majorities and officials and to establish them as legal principles to be applied by the courts.” Barnette, 319 U.S. at 638 . When fundamental rights are at stake, individuals "need not await legislative action.” Obergefell, 135 S. Ct. at 2605.

Indeed, in this sui generis circumstance, waiting is not an option. Those alive today are at perhaps the singular point in history where society (1) is scientifically aware of the impending climate crisis, and (2) can avoid the point of no return. And while democracy affords citizens the right "to debate so they can learn and decide and then, through the political process, act in concert to try to shape the course of their own times[,]" id. (quoting Schuette v. Coalition to Defend Affirmative Action, 572 U.S. 291, 312 (2014)), that process cannot override the laws of nature. Or, more colloquially, we can't shut the stable door after the horse has bolted.

As the last fifty years have made clear, telling plaintiffs that they must vindicate their right to a habitable United States through the political branches will rightfully be perceived as telling them they have no recourse. The political branches must often realize constitutional principles, but in a justiciable case or controversy, courts serve as the ultimate backstop. To this issue, I turn next.

B.

Of course, "it is not the role of courts, but that of the political branches, to shape the institutions of government in such fashion as to comply with the laws and the Constitution.” Lewis v. Casey, 518 U.S. 343, 349 (1996). So federal courts are not free to address every grievance. 
"Whether a party has a sufficient stake in an otherwise justiciable controversy to obtain judicial resolution of that controversy is what has traditionally been referred to as the question of standing to sue." Sierra Club v. Morton, 405 U.S. 727, 731-32 (1972). Standing is "a doctrine rooted in the traditional understanding of a case or controversy," developed to "ensure that federal courts do not exceed their authority as it has been traditionally understood." Spokeo, Inc. v. Robins, 136 S. Ct. 1540, 1547 (2016).

A case is fit for judicial determination only if the plaintiff has: "(1) suffered an injury in fact, (2) that is fairly traceable to the challenged conduct of the defendant, and (3) that is likely to be redressed by a favorable judicial decision." Id. (citing Lujan v. Defenders of Wildlife, 504 U.S. 555, 560-61 (1992); then citing Friends of the Earth, Inc. v. Laidlaw Envtl. Serv. (TOC), Inc., 528 U.S. 167, 180-81 (2000)). As to the first two elements, my colleagues and I agree: Plaintiffs present adequate evidence at this pre-trial stage to show particularized, concrete injuries to legally-protected interests, and they present further evidence to raise genuine disputes as to whether those injuries - at least in substantial part-are fairly traceable to the government's conduct at issue. See Maj. Op. at 18-21. Because I find that plaintiffs have also established the third prong for standing, redressability, I conclude that plaintiffs' legal stake in this action suffices to invoke the adjudicative powers of the federal bench.

\section{1.}

"Redressability" concerns whether a federal court is capable of vindicating a plaintiff's legal rights. I agree with the majority that our ability to provide redress is animated by two inquiries, one of efficacy and one of power. Maj. Op. at 21 (citing M.S. v. Brown, 902 F.3d 1076, 1083 (9th Cir. 
2018)). First, as a causal matter, is a court order likely to actually remediate the plaintiffs' injury? If so, does the judiciary have the constitutional authority to levy such an order? Id.

Addressing the first question, my colleagues are skeptical that curtailing the government's facilitation of fossil-fuel extraction and combustion will ameliorate the plaintiffs' harms. See Maj. Op. at 22-25. I am not, as the nature of the injury at stake informs the effectiveness of the remedy. See Warth, 422 U.S. at 500.

As described above, the right at issue is not to be entirely free from any climate change. Rather, plaintiffs have a constitutional right to be free from irreversible and catastrophic climate change. Plaintiffs have begun to feel certain concrete manifestations of this violation, ripening their case for litigation, but such prefatory harms are just the first barbs of an ongoing injury flowing from an ongoing violation of plaintiffs' rights. The bulk of the injury is yet to come. Therefore, practical redressability is not measured by our ability to stop climate change in its tracks and immediately undo the injuries that plaintiffs suffer todayan admittedly tall order; it is instead measured by our ability to curb by some meaningful degree what the record shows to be an otherwise inevitable march to the point of no return. Hence, the injury at issue is not climate change writ large; it is climate change beyond the threshold point of no return. As we approach that threshold, the significance of every emissions reduction is magnified.

The majority portrays any relief we can offer as just a drop in the bucket. See Maj. Op. at 22-25. In a previous generation, perhaps that characterization would carry the day and we would hold ourselves impotent to address plaintiffs' injuries. But we are perilously close to an overflowing 
bucket. These final drops matter. A lot. Properly framed, a court order - even one that merely postpones the day when remedial measures become insufficiently effective-would likely have a real impact on preventing the impending cataclysm. Accordingly, I conclude that the court could do something to help the plaintiffs before us.

And "something" is all that standing requires. In Massachusetts v. EPA, 549 U.S. 497 (2007), the Supreme Court explicitly held that a non-negligible reduction in emissions-there, by regulating vehicles emissionssatisfied the redressability requirement of Article III standing:

While it may be true that regulating motor-vehicle emissions will not by itself reverse global warming, it by no means follows that we lack jurisdiction to decide whether EPA has a duty to take steps to slow or reduce it. Because of the enormity of the potential consequences associated with manmade climate change, the fact that the effectiveness of a remedy might be delayed during the (relatively short) time it takes for a new motor-vehicle fleet to replace an older one is essentially irrelevant. Nor is it dispositive that developing countries such as China and India are poised to increase greenhouse gas emissions substantially over the next century: A reduction in domestic emissions would slow the pace of global emissions increases, no matter what happens elsewhere. 
... The risk of catastrophic harm, though remote, is nevertheless real.

Id. at 525-26 (internal citation omitted).

In other words, under Article III, a perceptible reduction in the advance of climate change is sufficient to redress a plaintiff's climate change-induced harms. Full stop. The majority dismisses this precedent because Massachusetts $v$. EPA involved a procedural harm, whereas plaintiffs here assert a purely substantive right. Maj. Op. at 24. But this difference in posture does not affect the outcome.

While the redressability requirement is relaxed in the procedural context, that does not mean (1) we must engage in a similarly relaxed analysis whenever we invoke Massachusetts v. EPA or (2) we cannot rely on Massachusetts $v$. EPA's substantive examination of the relationship between government action and the course of climate change. Accordingly, here, we do not consider the likelihood that plaintiffs will prevail in any newly-awarded agency procedure, nor whether granting access to that procedure will redress plaintiffs' injury. Cf. Massachusetts v. EPA, 549 U.S. at 517-18; Lujan, 504 U.S. at 572 n.7. Rather, we assume plaintiffs will prevail-removing the procedural link from the causal chain-and we resume our traditional analysis to determine whether the desired outcome would in fact redress plaintiffs' harms. $^{7}$ In

7 The presence of a procedural right is more critical when determining whether the first and second elements of standing are present. This is especially true where Congress has "define[d] injuries and articulate[d] chains of causation that will give rise to a case or controversy where none existed before" by conferring procedural rights that give certa in persons a "stake" in an injury that is otherwise not their own. Spokeo, 136 S. Ct. at 1549 (quoting Lujan, 504 U.S. at 580 
Massachusetts v. EPA, the remaining substantive inquiry was whether reducing emissions from fossil-fuel combustion would likely ameliorate climate change-induced injuries despite the global nature of climate change (regardless of whether renewed procedures were themselves likely to mandate such lessening). The Supreme Court unambiguously answered that question in the affirmative. That holding squarely applies to the instant facts, ${ }^{8}$ rendering the absence of a procedural right here irrelevant. ${ }^{9}$

(Kennedy, J., concurring)). But who seeks to vindicate an injury is irrelevant to the question of whether a court has the tools to relieve that injury.

${ }^{8}$ Indeed, the majority has a lrea dy a cknowledged as much in finding pla intiffs' injuries tra ceable to the government's misconduct because the traceability and redressability inquiries a re largely coextensive. See Maj. Op. at 19-21; see also Wash. Envtl. Council v. Bellon, 732 F.3d 1131, 1146 (2013) ("The Supreme Court has clarified that the 'fairly traceable' and 'redressability' components for standing overlap and are 'two facets of a single causation requirement.' The two are distinct insofar as causa lity examines the connection between the alleged misconduct and injury, whereas redressability analyzes the connection between the alleged injury and requested judicial relief.”) (internal citation omitted). Here, where the requested relief is simply to stop the ongoing misconduct, the inquiries are nearly identical. Cf. Allen v. Wright, 468 U.S. 737, 753 n.19 (1984) ("[I]t is important to keep the inquiries separate" where "the relief requested goes well beyond the violation of law alleged."), abrogated on other grounds by Lexmark Int'l, Inc. v. Static Control Components, Inc., 572 U.S. 118 (2014); see also infra Part II.B.3.

${ }^{9}$ Nor am I persuaded that Massachusetts v. EPA is distinguishable because of the relaxed standing requirements and "special solicitude" in cases brought by a state a ga inst the United States. Massachusetts v. EPA, 549 U.S. at 517-20. When Massachusetts v. EPA was decided, more than a decade ago, there was uncerta inty and skepticism as to whether an individual could state a sufficiently definite climate change-induced 
The majority laments that it cannot step into the shoes of the political branches, see Maj. Op. at 32, but appears ready to yield even if those branches walk the Nation over a cliff. This deference-to-a-fault promotes separation of powers to the detriment of our countervailing constitutional mandate to intervene where the political branches run afoul of our foundational principles. Our tripartite system of government is often and aptly described as one of "checks and balances." The doctrine of standing preserves balance among the branches by keeping separate questions of general governance and those of specific legal entitlement. But the doctrine of judicial review compels federal courts to fashion and effectuate relief to right legal wrongs, even when-as frequently happens-it requires that we instruct the other branches as to the constitutional limitations on their power. Indeed, sometimes "the [judicial and governance] roles briefly and partially coincide when a court, in granting relief against actual harm that has been suffered, ... orders the alteration of an institutional organization or procedure that causes the harm.” Lewis, 518 U.S. at 350; cf. Valley Forge Christian Coll. v. Ams. United for Separation of Church \& State, Inc., 454 U.S. 464, 474 (1982) ("Proper regard for the

harm based on gradually warming air temperatures and rising seas. But the Supreme Court sidestepped such questions of the concreteness of the plaintiffs' injuries by finding that "[Massachusetts's] stake in the outcome of this case is sufficiently concrete to warrant the exercise of federaljudicial power." Id. at 519. Here and now, the pla intiffs submit undisputed scientific evidence that their distinct and discrete injuries are caused by climate change brought about by emissions from fossil-fuel combustion. They need not rely on the "special solicitude," id. at 520, of a state to be heard. Regardless, any distinction would go to the concreteness or particularity of plaintiffs' injuries and not to the issue of redressability. 
complex nature of our constitutional structure requires neither that the Judicial Branch shrink from a confrontation with the other two coequal branches of the Federal Government, nor that it hospitably accept for adjudication claims of constitutional violation by other branches of government where the claimant has not suffered cognizable injury.”). In my view, this Court must confront and reconcile this tension before deciding that thorny questions of standing preclude review in this case. And faithful application of our history and precedents reveals that a failure to do so leads to the wrong result.

Taking the long (but essential) way around, I begin first by acknowledging explicitly what the majority does not mention: our history plainly establishes an ambient presumption of judicial review to which separation-ofpowers concerns provide a rebuttal under limited circumstances. Few would contest that "[i]t is emphatically the province and duty of the judicial department" to curb acts of the political branches that contravene those fundamental tenets of American life so dear as to be constitutionalized and thus removed from political whims. See Marbury, 5 U.S. at 177-78. This presumptive authority entails commensurate power to grant appropriate redress, as recognized in Marbury, "which effectively place[s] upon those who would deny the existence of an effective legal remedy the burden of showing why their case was special." Ziglar v. Abbasi, 137 S. Ct. 1843, 1874 (2017) (Breyer, J., dissenting). That is, "there must be something 'peculiar' (i.e., special) about a case that warrants 'excluding the injured party from legal redress and placing it within that class of cases which come under the description of damnum absque injuria-a loss without an injury."” Id. (cleaned up) (quoting Marbury, 5 U.S. at 163-64). In sum, although it is the plaintiffs' burden to establish injury in fact, causation, 
and redressability, it is the government's burden to establish why this otherwise-justiciable controversy implicates grander separation-of-powers concerns not already captured by those requirements. We do not otherwise abdicate our duty to enforce constitutional rights.

Without explicitly laying this groundwork, the majority nonetheless suggests that this case is "special" - and beyond our redress-because plaintiffs' requested relief requires (1) the messy business of evaluating competing policy considerations to steer the government away from fossil fuels and (2) the intimidating task of supervising implementation over many years, if not decades. See Maj. Op. at 25-27. I admit these are daunting tasks, but we are constitutionally empowered to undertake them. There is no justiciability exception for cases of great complexity and magnitude.

\section{3.}

I readily concede that courts must on occasion refrain from answering those questions that are truly reserved for the political branches, even where core constitutional precepts are implicated. This deference is known as the "political question doctrine," and its applicability is governed by a well-worn multifactor test that counsels judicial deference where there is:

[1] a textually demonstrable constitutional commitment of the issue to a coordinate political department; or [2] a lack of judicially discoverable and manageable standards for resolving it; or [3] the impossibility of deciding without an initial policy determination of a kind clearly for nonjudicial discretion; or [4] the 
impossibility of a court's undertaking independent resolution without expressing lack of the respect due coordinate branches of government; or [5] an unusual need for unquestioning adherence to a political decision already made; or [6] the potentiality of embarrassment from multifarious pronouncements by various departments on one question.

Baker v. Carr, 369 U.S. 186, 217 (1962); see also Zivotofsky ex rel. Zivotofsky v. Clinton, 566 U.S. 189, 195-201 (2012) (discussing and applying Baker factors); Vieth v. Jubelirer, 541 U.S. 267, 277-90 (2004) (same); Nixon v. United States, 506 U.S. 224, 228-38 (1993) (same); Chadha, 462 U.S. at 940-43 (same). ${ }^{\mathbf{1 0}}$ In some sense, these factors are frontloaded in significance. "We have characterized the first three factors as 'constitutional limitations of a court's jurisdiction' and the other three factors as 'prudential considerations."' Republic of Marshall Islands v. United States, 865 F.3d 1187, 1200 (9th Cir. 2017) (quoting Corrie

10 The political question doctrine was first conceived in Marbury. See Marbury, 5 U.S. at 165-66 ("By the constitution of the United States, the President is invested with certain important political powers, in the exercise of which he is to use his own discretion, and is accountable only to his country in his political character, and to his own conscience.”). The modern incarnation of the doctrine has existed relatively unaltered since its exposition in Baker in 1962. Although the majority disclaims the applicability of the political question doctrine, see Maj. Op. at 31, n.9, the opinion's references to the lack of discernable standards and its reliance on Rucho v. Common Cause, 139 S. Ct. 2484 (2019), as a basis for finding this case nonjusticiable blur any meaningful distinction between the doctrines of standing and political question. 
v. Caterpillar, Inc., 503 F.3d 974, 981 (9th Cir. 2007)). ${ }^{\mathbf{1 1}}$ Moreover, "we have recognized that the first two are likely the most important.” Marshall Islands, 865 F.3d at 1200 (citing Alperin v. Vatican Bank, 410 F.3d 532, 545 (9th Cir. 2005)). Yet, we have also recognized that the inquiry is highly case-specific, the factors "often collaps[e] into one another[,]" and any one factor of sufficient weight is enough to render a case unfit for judicial determination. See Marshall Islands, 865 F.3d at 1200 (first alteration in original) (quoting Alperin, 410 F.3d at 544). Regardless of any intra-factor flexibility and flow, however, there is a clear mandate to apply the political question doctrine both shrewdly and sparingly.

Unless one of these formulations is inextricable from the case at bar, there should be no dismissal for non-justiciability on the ground of a political question's presence. The doctrine of which we treat is one of 'political questions,' not one of 'political cases.' The courts cannot reject as 'no law suit' a bona fide controversy as to whether

11 The six Baker factors have been characterized as "reflect[ing] three distinct justifications for withholding judgment on the merits of a dispute." Zivotofsky v. Clinton, 566 U.S. at 203 (Sotomayor, J., concurring). Under the first Baker factor, "abstention is warranted because the court lacks authority to resolve" "issue[s] whose resolution is textually committed to a coordinate politicaldepartment[.]" Id. Under the second and third factors, abstention is warranted in "circumstances in which a dispute calls for decisionmaking beyond courts' competence[.]" Id. Under the final three factors, abstention is wa rranted where "prudence... counsel[s] against a court's resolution of an issue presented.” Id. at 204. 
some action denominated 'political' exceeds constitutional authority.

Baker, 369 U.S. at 217; see also Corrie, 503 F.3d at 982 ("We will not find a political question 'merely because [a] decision may have significant political overtones.”’) (quoting Japan Whaling Ass'n v. Am. Cetacean Soc'y, 478U.S. 221, 230 (1986)). Rather, when detecting the presence of a "political question," courts must make a "discriminating inquiry into the precise facts and posture of the particular case" and refrain from "resolution by any semantic cataloguing.” Baker, 369 U.S. at 217.

Here, confronted by difficult questions on the constitutionality of policy, the majority creates a minefield of politics en route to concluding that we cannot adjudicate this suit. And the majority's map for navigating that minefield is Rucho v. Common Cause, 139 S. Ct. 2484 (2019), an inapposite case about gerrymandering. My colleagues conclude that climate change is too political for the judiciary to touch by likening it to the process of political representatives drawing political maps to elect other political representatives. I vehemently disagree.

The government does not address on appeal the district judge's reasoning that the first, third, fourth, fifth and sixth Baker factors do not apply here. Neither does the majority rely on any of these factors in its analysis. In relevant part, I find the opinion below both thorough and well-reasoned, and I ad opt its conclusions. I note, however, that the absence of the first Baker factor-whether the Constitution textually delegates the relevant subject matter to another branch-is especially conspicuous. As the district judge described, courts invoke this factor only where the Constitution makes an unambiguous commitment of responsibility to one branch 
of government. Very few cases turn on this factor, and almost all that do pertain to two areas of constitutional authority: foreign policy and legislative proceedings. See, e.g., Marshall Islands, 865 F.3d at 1200-01 (treaty enforcement); Corrie, 503 F.3d at 983 (military aid); Nixon, 506 U.S. at 234 (impeachment proceedings); see also Davis v. Passman, 442 U.S. 228, 235 n.11 (1979) (“[J]udicial review of congressional employment decisions is constitutionally limited only by the reach of the Speech or Debate Clause[,] ... [which is] a paradigm example of a textually demonstrable constitutional commitment of [an] issue to a coordinate political department.”) (internal quotation marks omitted); Zivotofsky ex rel. Zivotofsky $v$. Kerry, 135 S. Ct. 2076, 2086 (2015) ("The text and structure of the Constitution grant the President the power to recognize foreign nations and governments.”).

Since this matter has been under submission, the Supreme Court cordoned off an additional area from judicial review based in part on a textual commitment to another branch: partisan gerrymandering. See Rucho, 139 S. Ct. at 2494-96. ${ }^{12}$ Obviously, the Constitution does not explicitly address climate change. But neither does climate change implicitly fall within a recognized political-question area. As the district judge described, the questions of energy

12 Rucho does not turn exclusively on the first Baker factor and acknowledges that there are some areas of districting that courts may police, notwithstanding the Elections Clause's "assign[ment] to state legislatures the power to prescribe the 'Times, Places and Manner of holding Elections' for Members of Congress, while giving Congress the power to 'make or alter' any such regulations." Rucho, 139 S. Ct. at 2495. Instead, Rucho holds that a combination of the text (as illuminated by historical practice) and absence of clearjudicial standards precludes judicial review of excessively partisan gerrymanders. See infra Part II.B.4. 
policy at stake here may have rippling effects on foreign policy considerations, but that is not enough to wholly exempt the subject matter from our review. See Juliana $v$. United States, 217 F. Supp. 3d 1224, 1238 (D. Or. 2016) ("[U]nlike the decisions to go to war, take action to keep a particular foreign leader in power, or give aid to another country, climate change policy is not inherently, or even primarily, a foreign policy decision.”); see also Baker, 369 U.S. at 211 ("[I]t is error to suppose that every case or controversy which touches foreign relations lies beyond judicial cognizance.”).

Without endorsement from the constitutional text, the majority's theory is grounded exclusively in the second Baker factor: a (supposed) lack of clear judicial standards for shaping relief. Relying heavily on Rucho, the majority contends that we cannot formulate standards (1) to determine what relief "is sufficient to remediate the claimed constitutional violation" or (2) to "supervise[] or enforce[]" such relief. Maj. Op. at 29.

The first point is a red herring. Plaintiffs submit ample evidence that there is a discernable "tipping point" at which the government's conduct turns from facilitating mere pollution to inducing an unstoppable cataclysm in violation of plaintiffs' rights. Indeed, the majority itself cites plaintiffs' evidence that "atmospheric carbon levels of 350 parts per million are necessary to stabilize the climate." Id. at 24. This clear line stands in stark contrast to Rucho, which held that-even assuming an excessively partisan gerrymander was unconstitutional-no standards exist by which to determine when a rights violation has even occurred. There, "[t]he central problem [wa]s not determining whether a jurisdiction has engaged in partisan gerrymandering. It [wa]s determining when political 
gerrymandering has gone too far.” Rucho, 139 S. Ct. at 2497 (internal quotation marks omitted); see also id. at 2498 ("[T]he question is one of degree: How to provide a standard for deciding how much partisan dominance is too much.”) (internal quotation marks omitted); id. at 2499 ("If federal courts are to .... adjudicat[e] partisan gerrymandering claims, they must be armed with a standard that can reliably differentiate unconstitutional from constitutional political gerrymandering.”) (internal quotation marks and citation omitted).

Here, the right at issue is fundamentally one of a discernable standard: the amount of fossil-fuel emissions that will irreparably devastate our Nation. That amount can be established by scientific evidence like that proffered by the plaintiffs. Moreover, we need not definitively determine that standard today. Rather, we need conclude only that plaintiffs have submitted sufficient evidence to create a genuine dispute as to whether such an amount can possibly be determined as a matter of scientific fact. Plaintiffs easily clear this bar. Of course, plaintiffs will have to carry their burden of proof to establish this fact in order to prevail at trial, but that issue is not before us. We must not get ahead of ourselves.

The procedural posture of this case also informs the question of oversight and enforcement. It appears the majority's real concerns lie not in the judiciary's ability to draw a line between lawful and unlawful conduct, but in our ability to equitably walk the government back from that line without wholly subverting the authority of our coequal branches. My colleagues take great issue with plaintiffs' request for a "plan" to reduce fossil-fuel emissions. I am not so concerned. At this stage, we need not promise plaintiffs the moon (or, more apropos, the earth in a habitable state). 
For purposes of standing, we need hold only that the trial court could fashion some sort of meaningful relief should plaintiffs prevail on the merits. ${ }^{13}$

Nor would any such remedial "plan” necessarily require the courts to muck around in policymaking to an impermissible degree; the scope and number of policies a court would have to reform to provide relief is irrelevant to the second Baker factor, which asks only if there are judicially discernable standards to guide that reformation. Indeed, our history is no stranger to widespread, programmatic changes in government functions ushered in by the judiciary's commitment to requiring adherence to the Constitution. Upholding the Constitution's prohibition on cruel and unusual punishment, for example, the Court ordered the overhaul of prisons in the Nation's most populous state. See Brown v. Plata, 563 U.S. 493, 511 (2011) ("Courts may not allow constitutional violations to continue simply because a remedy would involve intrusion into the realm of prison administration.”) And in its finest hour, the Court mandated the racial integration of every public school — state and federal—in the Nation, vindicating the Constitution's guarantee of equal protection under the law. ${ }^{14}$ See Brown v. Bd. of Educ. (Brown I), 347 U.S. 483

${ }^{13}$ It is possible, of course, that the district court ultimately concludes that it is unable to provide meaningfulredress based on the facts proved at trial, but trial has not yet occurred. Our present occasion is to decide only whether plaintiffs have ra ised a genuine dispute as to the judiciary's ability to provide meaningful redress under any subset of the facts at issue today. See Maj. Op. at 18 (citing Cent. Delta Water Agency v. United States, 306 F.3d 938, 947 (9th Cir. 2002)).

${ }^{14}$ In contrast, we are haunted by the days we declined to curtail the government's approval of invidious discrimination in public life, see Plessy v. Ferguson, 163 U.S. 537, 559 (1896) (Harlan, J., dissenting) 
(1954); Bolling v. Sharpe, 347 U.S. 497 (1954). In the school desegregation cases, the Supreme Court was explicitly unconcerned with the fact that crafting relief would require individualized review of thousands of state and local policies that facilitated segregation. Rather, a unanimous Court held that the judiciary could work to dissemble segregation over time while remaining cognizant of the many public interests at stake:

To effectuate [the plaintiffs'] interest[s] may call for elimination of a variety of obstacles in making the transition to school systems operated in accordance with the constitutional principles set forth in [Brown I]. Courts of equity may properly take into account the public interest in the elimination of such obstacles in a systematic and effective manner. But it should go without saying that the vitality of these constitutional principles cannot be allowed to yield simply because of disagreement with them.

... [T]he courts may find that additional time is necessary to carry out the ruling in an effective manner. The burden rests upon the defendants to establish that such time is necessary in the public interest and is consistent with good faith compliance at the

("[T]he judgment this day rendered will, in time, prove to be quite as pernicious as the decision made by this tribunal in the Dred Scott Case."), and neglected to free thousands of innocents prejudicially interned by their own government without cause, see Trump v. Hawaii, $138 \mathrm{~S}$. Ct. 2392, 2423 (2018) ("Korematsu was gravely wrong the day it was decided[.]"). 
earliest practicable date. To that end, the courts may consider problems related to administration, arising from the physical condition of the school plant, the school transportation system, personnel, revision of school districts and attendance areas into compact units to achieve a system of determining admission to the public schools on a nonracial basis, and revision of local laws and regulations which may be necessary in solving the foregoing problems.

Brown v. Bd. of Educ. (Brown II), 349 U.S. 294, 300-01 (1955).

As we are all too aware, it took decades to even partially realize Brown's promise, but the slow churn of constitutional vindication did not dissuade the Brown Court, and it should not dissuade us here. Plaintiffs' request for a "plan" is neither novel nor judicially incognizable. Rather, consistent with our historical practices, their request is a recognition that remedying decades of institutionalized violations may take some time. Here, too, decelerating from our path toward cataclysm will undoubtedly require "elimination of a variety of obstacles." Those obstacles may be great in number, novelty, and magnitude, but there is no indication that they are devoid of discernable standards. Busing mandates, facilities allocation, and district-drawing were all "complex policy decisions" faced by post-Brown trial courts, see Maj. Op. at 25, and I have no doubt that disentangling the government from promotion of fossil fuels will take an equally deft judicial hand. Mere complexity, however, does not put the issue out of the courts' reach. Neither the government nor the majority has articulated why 
the courts could not weigh scientific and prudential considerations - as we often do - to put the government on a path to constitutional compliance.

The majority also expresses concern that any remedial plan would require us to compel "the adoption of a comprehensive scheme to decrease fossil fuel emissions and combat climate change[.]" Id. at 25. Even if the operative complaint is fairly read as requesting an affirmative scheme to address all drivers of climate change, however caused, see id. at 23 n.6., such an overbroad request does not doom our ability to redress those drivers implicated by the conduct at issue here. Courts routinely grant plaintiffs less than the full gamut of requested relief, and our inability to compel legislation that addresses emissions beyond the scope of this case - such as those purely in the private sphere or within the control of foreign governments - speaks nothing to our ability to enjoin the government from exercising its discretion in violation of plaintiffs' constitutional rights.

\section{4.}

In sum, resolution of this action requires answers only to scientific questions, not political ones. And plaintiffs have put forth sufficient evidence demonstrating their entitlement to have those questions addressed at trial in a court of law.

As discussed above, the majority reaches the opposite conclusion not by marching purposefully through the Baker factors, which carve out a narrow set of nonjusticiable political cases, but instead by broadly invoking Rucho in a manner that would cull from our dockets any case that presents administrative issues "too difficult for the judiciary to manage." Maj. Op. at 28. That simply is not the test. Difficult questions are not necessarily political questions and, beyond reaching the wrong conclusion in this case, the 
majority's application of Rucho threatens to eviscerate judicial review in a swath of complicated but plainly apolitical contexts.

Rucho's limitations should be apparent on the face of that opinion. Rucho addresses the political process itself, namely whether the metastasis of partisan politics has unconstitutionally invaded the drawing of political districts within states. Indeed, the Rucho opinion characterizes the issue before it as a request for the Court to reallocate political power between the major parties. Rucho, 139 S. Ct. at 2502, 2507, 2508. Baker factors aside, Rucho surely confronts fundamentally "political” questions in the common sense of the term. Nothing about climate change, however, is inherently political. The majority is correct that redressing climate change will require consideration of scientific, economic, energy, and other policy factors. But that endeavor does not implicate the way we elect representatives, assign governmental powers, or otherwise structure our polity.

Regardless, we do not limit our jurisdiction based on common parlance. Instead, legal and constitutional principles define the ambit of our authority. In the present case, the Baker factors provide the relevant guide and further distinguish Rucho. As noted above, Rucho's holding that policing partisan gerrymandering is beyond the courts' competence rests heavily on the first Baker factor, i.e., the textual and historical delegation of electoral-district drawing to state legislatures. The Rucho Court decided it could not discern mathematical standards to navigate a way out of that particular political thicket. It did not, however, hold that mathematical (or scientific) difficulties in creating appropriate standards divest jurisdiction in any context. 
Such an expansive reading of Rucho would permit the "political question" exception to swallow the rule.

Global warming is certainly an imposing conundrum, but so are diversity in higher education, the intersection between prenatal life and maternal health, the role of religion in civic society, and many other social concerns. Cf. Regents of the Univ. of Cal. v. Bakke, 438 U.S. 265, 360 (1978) ("[T]he line between honest and thoughtful appraisal of the effects of past discrimination and paternalistic stereotyping is not so clear[.]"); Planned Parenthood of Se. Pa. v. Casey, 505 U.S. 833, 871 (1992) (stating that Roe v. Wade, 410 U.S. 113 (1973), involved the "difficult question" of determining the "weight to be given [the] state interest" in light of the "strength of the woman's [privacy] interest"); Am. Legion v. Am. Humanist Ass'n, 139 S. Ct. 2067, 2094 (2019) (Kavanaugh, J., concurring) (noting that determining the constitutionality of a large cross's presence on public land was "difficult because it represents a clash of genuine and important interests"). These issues may not have been considered within the purview of the judicial branch had the Court imported wholesale Rucho's "manageable standards" analysis even in the absence of Rucho's inherently political underpinnings. Beyond the outcome of the instant case, I fear that the majority's holding strikes a powerful blow to our ability to hear important cases of widespread concern.

\section{III.}

To be sure, unless there is a constitutional violation, courts should allow the democratic and political processes to perform their functions. And while all would now readily agree that the 91 years between the Emancipation Proclamation and the decision in Brown v. Board was too long, determining when a court must step in to protect 
fundamental rights is not an exact science. In this case, my colleagues say that time is "never"; I say it is now.

Were we addressing a matter of social injustice, one might sincerely lament any delay, but take solace that "the arc of the moral universe is long, but it bends towards justice." 15 The denial of an individual, constitutional rightthough grievous and harmful—can be corrected in the future, even if it takes 91 years. And that possibility provides hope for future generations.

Where is the hope in today's decision? Plaintiffs' claims are based on science, specifically, an impending point of no return. If plaintiffs' fears, backed by the government's own studies, prove true, history will not judge us kindly. When the seas envelop our coastal cities, fires and droughts haunt our interiors, and storms ravage everything between, those remaining will ask: Why did so many do so little?

I would hold that plaintiffs have standing to challenge the government's conduct, have articulated claims under the Constitution, and have presented sufficient evidence to press those claims at trial. I would therefore affirm the district court.

With respect, I dissent.

15 Dr. Martin Luther King, Jr., Remaining Awake Through a Great Revolution, Address at the National Cathedral, Washington, D.C. (Mar. 31, 1968). In coining this language, Dr. King was inspired by an 1853 sermon by abolitionist Theodore Parker. See Theodore Parker, Of Justice and the Conscience, in Ten Sermons of Religion 84-85 (Boston, Crosby, Nichols \& Co. 1853). 